YEARBOOK
of ANTITRUST
and REGULATORY
STUDIES
www.yars.wz.uw.edu.pl
Peer-reviewed scientific periodical, focusing on legal and economic issues of antitrust and regulation. Creative Commons Attribution-No Derivative Works 3.0 Poland License.

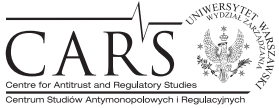

Centre for Antitrust and Regulatory Studies, University of Warsaw, Faculty of Management www.cars.wZ.uw.edu.pl

\title{
Differentiation between entrepreneurs (on the basis of the public task criterion) and its legal consequences. Case comment to the judgment of the Court of Appeals in Warsaw of 21 April 2011 \\ President of Office of Competition and Consumer Protection v Polish Football Association and Canal+ Sp. z.o.o. (Ref. no. VI ACa 996/10)
}

\section{Introduction}

The discussed judgment was rendered in relation to the dispute between the President of the Polish Competition Authority (hereafter, UOKiK President) on the one hand and the Polish Football Association and the broadcaster Canal+ on the other hand. These two undertakings were party to an agreement on exercising media rights to football games of the two highest classes of the Polish league. The core of the dispute consisted of the possibility of deeming the pre-emption right reserved for Canal+ as a contractual provision restricting competition. The Courts involved were also forced to answer the question whether performing tasks of a public service character justified a decrease in the fine imposed by the competition authority

\section{Findings of fact}

The Polish Football Association (hereafter, PZPN), with its registered office in Warsaw, is a nation-wide sports association representing Polish football (indoor eleven, beach, men and women $)^{1}$. PZPN functions on the basis of the Act on Physical Culture of 18 January $1996^{2}$, the Law on Associations of 7 April 1989², statutes of FIFA (Fédération Internationale de Football Association) and UEFA (Union of European Football Associations) as well as the statute of PZPN itself. Its tasks include, among others, preparing for and entering the national team, as well as other teams representing Poland, into international games, organizing and conducting a nation-wide system of

\footnotetext{
1 Article 4 of the Statute of the Polish Football Association (hereafter, Statute).

2 Act of 18 January 1996 on Physical Culture (consolidated text: Journal of Laws 2001 No. 81 , item 889 , as amended).

3 Act of 07 April 1989 - Law on Associations (Journal of Laws 1989 No. 79, item 855, as amended).
} 
football games and cup tournaments in all age categories with the view to establish the Champion of Poland, the Winner of the Polish Cup, Polish League Cup and Polish SuperCup as well as international and interstate competitions.

PZPN is the sole owner of all proprietary and non-proprietary rights to international and interstate games of the Polish national team ${ }^{4}$ in various age categories as well as to the football games organized by PZPN itself including, primarily, all broadcasting, advertising and marketing rights to its matches via all available means of audio-visual, audio, Internet and other technical transmission models existing currently or in future.

Canal+ Cyfrowy (hereafter, Canal+), registered office in Warsaw, is a subsidiary of Groupe Canal+ S.A. Its activity consists of broadcasting pay-TV channels via its satellite digital distribution platform 'Cyfra+' and the creation of premium movie and sports channels. In order to develop its offer, Canal+ enters into license agreements for broadcasting rights to movies, sport events and other audiovisual content. Canal+ produces also a small amount of content directly which is incorporated into its TV channels including, above all, recordings of Polish league football games, sportoriented programmes and auto-promotion spots.

As football continues to enjoy enormous and constant popularity in Poland, the rights to broadcast league matches are of considerable financial value. They constitute a highly desirable commodity on the Polish market for broadcasting rights. PZPN exercises the exclusive right to trade in the broadcasting rights to football matches played in the tournaments it organizes. On 27 July 2000, PZPN concluded a license agreement (hereafter, Agreement) with Polska Korporacja Telewizyjna granting the latter an exclusive license for exercising media rights to football matches of the two highest match classes of the Polish league: the Polish Cup and Polish League Cup. On 28 February 2002, the rights covered by this Agreement were assigned to Canal+ Cyfrowy. It is worth noting that the rights in question were exercised by the same broadcaster, 'Canal+', throughout the whole term of the license.

The licensed broadcasting rights included all exclusive rights to make the course of any football match available to any audience in whole or in part, as well as exclusiveness to the so-called 'access to information' on all areas of exploitation (hereafter, Rights). They were granted for the period of time starting with the 2000/2001 season (league matches), 2001/2002 (Polish Cup matches) and 2002/2003 (Polish League Cup matches) and lasted until the 2004/2005 season. The Agreement contained also a specific provision on access to the Right for the 2005/2006 up to 2008/2009 seasons - Article 5 of the Agreement irrevocably assigned 'the pre-emption right to obtain an exclusive license for exercising the Rights in the seasons 2005/2006, 2006/2007, 2007/2008, 2008/2009 to PKT (Canal+)' (hereafter, pre-emption right).

The pre-emption right was to be exercised in the following manner: in case PZPN obtained an offer to purchase the Rights or to obtain a license for exercising these Rights within the term of the Agreement, it was obliged within 60 days at the latest but not earlier than 90 days before the expiry of the Agreement, to notify Canal+ in writing of such offer indicating its conditions. Canal+ could notify PZPN within 30

\footnotetext{
${ }^{4}$ Article 14 of the Statute.
} 
days if it would exercise its pre-emption right. PZPN was then obliged to conclude a new agreement granting an exclusive license for the period covered by the preemption right on conditions identical to those of the most favorable offer made to PZPN in good faith by another entity ${ }^{5}$. It is this very provision which constituted the basis for the dispute touching upon the issue of competition protection.

On 15 November 2004, PZPN invited both TV broadcasters and Internet operators to participate in a tender for the purchase of audio-visual rights to league matches for the seasons from 2005/2006 to 2007/2008. All potential bidders for the Main Broadcaster's Package were informed that for contractual reasons, Canal+ enjoyed a special right to submit offers for individual packages, that is, had the unilateral option of purchasing rights included in the Main Broadcaster's Package on the best conditions offered by any other bidder.

Offers for the licenses in question were placed by the following entities: Canal+ (Main Broadcaster's Package, Derby Match Package, Discussion Forum), Telewizja Polsat (all packages aside from Internet and Inside Ring rights), Grupa TVN (Sunday Shorts' Package, Information Access Package), Grupa Multimedialna (TV Centrum all packages aside for Internet and Inside Ring rights), Interia.pl (Internet Packages), Onet (Internet Packages), Agora (Internet Packages), Multikino (Inside Ring). The public service broadcasters, TVP, refrained from the participation in the tender. After the completion of the tender, individual packages were purchased by the highest bidders: Canal+ (Main Broadcaster's Package, Derby Match Package, Discussion Forum); Grupa TVN (Sunday Shorts' Package, Information Access Package), Multikino (Inside Circle) and Onet., Interia.pl, Agora (Internet packages).

In the course of the competition proceedings the UOKiK President asked the biggest Polish TV broadcasters (TVP, Polsat, TVN) how were they influenced in the tender by the disclosure of the existence of the pre-emption right and, in particular, as to their decision to participate in the tender or amount of the offer.

Polsat stated that finding out of the existence of the pre-emption right influenced its participation in the tender only indirectly. The broadcaster decided to submit the bid regardless of the fact that the pre-emption right was assigned to its competitor. Polsat was aware that the sought rights would doubtlessly improve the attractiveness of its offer. It saw its own bid as competitive, very attractive in relation to distribution (broadcasting games in free-to-air as well as encoded channels) and reliability (many years of experience in TV transmissions for key sports events) as well as finance. Upon the closure of the tender, the broadcaster was only briefly notified that its offer was not selected, and was provided neither with details nor reasons for the rejection. Polsat stated that the pre-emption right differentiated the conditions of the tender with respect to its participants because it placed Canal+ in a privileged position with respect to similar offers in terms of programme and finance.

By contrast, TVN stated that the conditions of the tender bore no influence on the possibility of purchasing the package it was seeking (Shorts' Package) because

\footnotetext{
5 Decision of the UOKiK President of 29 May 2006, DOK-49/06.
} 
any purchaser of the Main Broadcaster's Package was obliged to cooperate with the purchaser of the Shorts' Package on the same principles (Decision DOK-49/06).

In response to the charge of an anti-competitive nature of the pre-emption right, PZPN argued that the contested right granted to Canal+ in the agreement of 27 July 2000 is subject to existing Polish civil law provisions. PZPN argued that granting of pre-emption rights is permitted without any restrictions under Polish law and as such it may not be questioned as the conduct of the parties remains in accordance with Article 596 of the Polish Civil Code.

PZPN stated also that the rights covered by the tender were divided into several individual packages, a fact that should prove the Association's deliberate attempt to diversify the offer. PZPN said to have employed this approach in order to facilitate tender participation by a wide range of potential bidders. All invited participants had the chance to place a bid on their own conditions within the exploitation purpose of the package they selected. In the opinion of PZPN, this approach was a considerable facilitation for potential bidders as they could license the package they found most attractive in light of their needs and programme policy. Leading broadcasters such as Canal+ and TVN were thus said to have made use of this possibility and purchased packages they were most interested in. Only Canal+ made an all-inclusive offer for the Main Broadcaster's Package that corresponded fully with PZPN'S requirements set in the tender invitation.

The result of the tender would have, in PZPN's opinion, looked similar even if Canal+ had not enjoyed the pre-emption right. According to the Association, TVP's choice not to participate in the tender reflected its conscious decision not to take the opportunity of placing a better offer than that of Canal+. Furthermore, the preemption right assigned to Canal+ was not actually made use of as Canal+ outright submitted the highest bid of all.

PZPN questioned also the definition of the relevant market adopted by the UOKiK President. Resting upon the data from a consumer preference survey report commissioned by the competition authority, the Association concluded that the relevant market for transmission rights to football matches should include all and not just the matches of the Polish league.

Canal+ was of the opinion that it could not be charged with activities meant to foreclose the rights market for the broadcasting of football matches of the Polish league. Canal+, similarly to other tended participants, did not influence the ultimate choice made by PZPN, apart from doing their best to make its offer financially attractive. The broadcaster stated that it did not take any actions which, even potentially, would negatively influence the decisions of its competitors as to the participation in the tender. Referring to the pre-emption right, Canal+ stated that its absence would not have increased general interest in PZPN's offer. The broadcaster stressed that the propositions concerning the possibility of broadcasting football matches of the Polish league made by PZPN to other entities were not received by them with any interest. The well-established market position of Canal+ was, in its own view, a factor stabilizing the relevant market - this fact should not put it in a negative light as this would lead to a situation where each of its contracts could be deemed an anti-competitive practice. 
Canal+ claimed also that no infringement of the public interest (set of clearly and well-determined interests of the general public) occurred in this case. The broadcaster quoted a Supreme Court judgment of 29 May $2001^{6}$, which states that only activities touching upon the sphere of interests of a wider circle of market participants infringe competition.

According to Canal+, the existence of the pre-emption right does not result in eliminating competition but just the opposite: it makes the interested entities compete with each other with respect to the offered conditions and, above all, in relation to price. The company believes that tender participants were free to place their bids while PZPN was free to conduct negotiations in order to select the best offer (which could have exceeded the financial possibilities of Canal+) and ultimately, to select the winner.

After conducting the proceedings, the UOKiK President refuted the arguments of the two companies concerned and issued a decision that deemed the agreement in question as restricting competition (DOK-49/06). A fine was imposed upon PZPN and Canal + in the amount of PLN 443998.73 (app. $€ 111$ 000) and PLN 7368712.05 (app. $€ 1842$ 000) respectively. Moreover, the UOKiK President obliged the parties to reimburse the costs of the proceedings in the amount of PLN 12932 (app $€ 3$ 200).

The UOKiK President stated that 'As PZPN possesses a 100\% market share in the market of trading in rights to broadcast Polish football league matches, each activity of this entity which may infringe the principles of free competition undertaken, above all, in agreement with the purchasers of rights constituting the object of trade, considerably influences the position of other (including potential) purchasers of such rights, i.e. television broadcasters interested in purchasing the right to broadcast other than Canal+, and indirectly - a wide circle of consumers - viewers of television channels broadcast by competing television broadcasters'. With reference to the importance of the pre-emption right, the UOKiK President stated only that 'It remains outside the dispute that granting the pre-emption right $[\ldots]$ puts Canal+ in a privileged position in comparison with its competitors interested in acquiring such rights. Stating that the aforementioned right is prohibited requires, however, a justification. It should therefore be considered whether the elimination, restriction or infringement of competition on the relevant market in another manner constituted the aim or the effect [Article 5(1) of the Act] of granting Canal+ the pre-emption right'.

Both companies appealed the antitrust decision to the Regional Court in Warsaw - the Court for Competition and Consumer Protection (hereafter, SOKiK) requesting for the decision to be reversed or, as a precaution if that request was refused, for the decision to be changed by lowering the fines imposed.

After an examination, SOKiK changed the contested decision in a judgment of 14 February 2007 by lowering the fine imposed on PZPN to the amount of PLN 221999.37 (app $€ 56$ 000) (half of the original fine). The remaining part of PZPN's appeal was dismissed as was the entirely of the appeal submitted by Canal+.

Both companies appealed and in a judgment of 4 December 2007, the Court of Appeals in Warsaw reversed SOKiK's judgment with respect to the amount of the

6 Judgment of the Supreme Court of 29 May 2001, I CKN 1217/98, (2002) 1 OSNC item 12. 
fine and transferred the case to be re-heard by the SOKiK in this respect. Canal+ submitted the final appeal in this case but it was dismissed by the Supreme Court in a judgment of 7 January 2009 (file No. III SK 16/08).

As a result of the renewed hearing of PZPN's appeal from the antitrust decision of 29 May 2006 by SOKiK, PZPN's fine was yet again set by SOKiK to PLN 221 999.37.

The renewed SOKiK judgment was appealed by the UOKiK President in its entirety. The competition authority claimed that SOKiK wrongly connected the amount of the fine with the performance by PZPN of tasks of a public character.

In a judgment 21 April 2011 (file No. VIA Ca 996/10), the Court of Appeals reversed SOKiK's newer judgment dismissing PZPN's appeal within the scope of the decision concerning the fine. It was stressed in the reasoning to the judgment that the performance of tasks of a public character cannot constitute a factor influencing the graduation of the fine imposed upon such entity. According to the Court of Appeals, a different interpretation would lead to the creation of a group of entrepreneurs treated by the competition authority in a more lenient way than others.

\section{Legal analysis}

Although the discussed judgment limits itself to the issue of PZPN's fine, it would be useful to expand this commentary to two additional issues related to the correctness of the entire proceedings which ultimately ended in the judgment of the Court of Appeals.

The first issue relates to the possibility of deeming the pre-emption right to be a contractual provision restricting competition and the second relates to the opinion of the UOKiK President (supported by the courts) that the pre-emption right included in the agreement between PZPN and Canal+ constituted an infringement of the rules contained in the Polish Competition Act.

\section{Pre-emption right, general remarks}

Among the controversies of the discussed case is the fact that the granting of the pre-emption right was deemed by the UOKiK President to constitute a competition restricting practice ${ }^{7}$. Taking into consideration the principle expressed in Article $353^{1}$ of the Polish Civil Code, as well as the fact that pre-emption rights constitute a well established institution of the Polish legal system, the authority had to ascertain whether the contested clause contradicts the act (and if so - in what way). The UOKiK President's analysis should have been particularly diligent here as the clause in question is regulated by the Civil Code and widely used in trade relations, among others, by entities which find themselves in situations closely resembling the case at hand.

Limiting the application of a legal institution (such as the use of pre-emption rights) in relation to a certain group of entities by way of an administrative decisions

7 J. Sroczyński observes here the similarity to the so-called English clause - see 'The Permissibility of Exclusive Transactions: Few Remarks in the Context of Exercising Media Rights' (2010) 3(3) YARS 128 and on. 
and its judicial review demands that the issuing authority accurately specifies the criteria considered. Such situation should constitute an exception to the general permissibility of the use of such clause - an exception that cannot be interpreted widely. In other words, the UOKiK President and the adjudicating courts should have clearly identified what exactly - in the specific economic context - the threat to competition resulting from the application of the pre-emption right consisted off. The lack of such definition could result in the elimination of the use of a legal institution that often realizes important social objectives. Even if the conclusion of this judicial review were to consist of the prohibition to use pre-emption rights in agreements concluded by a monopolistic or dominant entity, then such conclusion should have been fully explained to ensure legal certainty. Due to the frequent use of pre-emption rights in the trade in national cultural goods, for instance, which often involve a dominant undertaking (similarly to broadcasting rights), the correctness of the antitrust decision and the resulting jurisprudence must be criticized for their lack of precise interpretation guidelines of the issue at hand.

\section{Pre-emption right in the Agreement}

Canal+ did not actually exercise its pre-emption right because its offer emerged as the highest of the tender. Canal+'s opinion should be supported that the mere reservation of the pre-emption right in the Agreement did not exclude the possibility of another entity winning the tender, provided the latter submitted a better offer. All bidders act in their own best understood interest submitting bids which are to bring them maximum profits. If so, Canal+ would surely not exercise the pre-emption right if a competing offer exceeded its financial capabilities (rationality of the purchase taking into consideration the advertising potential of the rights). The fact that the tender procedure made it impossible to modify an offer already placed forced all participants to submit maximum bids out front. Since bidders are separate entities, they inure different costs and can expect different profits from the rights. Canal+'s advantage resulting from the pre-emption right is therefore purely theoretical. In essence, it reflects the possibility to purchase the given commodities for the highest price offered but without having to participate in a tender. According to the UOKiK President, the competition infringement manifested itself in the fact that PZPN was obliged to inform Canal+ about the conditions of competing offers. The Authority stressed in its decision: 'PZPN's obligation to disclose competing offers resulted in an asymmetry of information between Canal+ and other potential bidders. As a result, a potential competitor of Canal+, in order to have a chance to obtain the broadcasting right, had to make an offer attractive enough to be sure that Canal+ would be unable to pay the same amount for obtaining the license. At the same time, when placing its primary bid, [Canal+] could offer an amount even many times lower than its competitors knowing that if its bid is topped, it may increase its offer to the level set by a competitor'8.

\footnotetext{
8 Decision of the UOKiK President of 29 May 2006, DOK-49/06.
} 
Moreover, '(...) according to the UOKiK President, the agreement in question resulted in a restriction of competition on the relevant market. What constituted such an effect was TVP's resignation from participating in the tender directly caused by the awareness of the existence of the contract granting a privileged position to TVP's competitor [, that is, Canal+] in applying for the rights this broadcaster was interested in'. In the opinion of the UOKiK President, knowing about the existence of the Agreement resulted therefore in other entities resigning from the participation in the tender. This conclusion is not logical - to agree with it would mean that the sole fact of Canal+'s participation in the tender could discourage its competitors from entering because, being a large market player, Canal+ could submit a high bid. The authority's view supports a fictional situation whereby an entrepreneur (Canal+) does not make profit-oriented commercial decisions but aims to win the tender at all costs.

The UOKiK President's incorrect standpoint was shared by SOKiK. 'In reference to the fines imposed, one should have taken into consideration that the fact of concluding the agreement prohibited in Article 5 [Competition Act] justified imposing fines on the parties to that agreement pursuant to Article 101(1)(1) of the Act. The advisability of the imposed fines is supported by the fact that the existence of the subjective option clause impacts market competition in such a way that it is scarcely probable that the injured entities shall make their claims. Proving it by, for example, an entity resigning from entering the market for this reason would be difficult ${ }^{9}$. A conclusion may be drawn from SOKiK's reasoning whereby the lack of evidence of an actual market impact can justify the imposition of a fine. It should be noted that due to the repressive character of fines in antitrust proceedings, the use of principles relating to penal proceedings should be supported including, most of all, the in dubio pro reo rule. It is thus necessary to oppose the approach adopted by SOKiK because of the inability to prove that the conduct of others was in fact determined by the existence of the pre-emption right.

Clearly however, lack of evidence is not sufficient to justify the statement that the Agreement did not have anti-competitive features. The authority is obliged to protect the public interest rather than that of particular market participants. In the discussed case, the pure existence of the pre-emption right was deemed to constitute an infringement of the public interest by both the UOKiK President as well as the adjudicating courts.

According to SOKiK: '(...) it is not important that Canal+ did not exercise the right of option seeing as it placed the most favorable offer, because just the information that this entity has a guaranteed privileged position in a prospective tender [...] resulted in the fact that potential competitors could not expect to win it [.] Canal+ has much greater possibilities of gaining profits from the acquired rights [mostly because of] its longer market presence [and the fact that it] has partly amortized its costs and possesses a well developed distribution network and a steady customer base'.

According to SOKiK, this situation had an unfavorable influence on the position of consumers. The Court stated in its reasoning that the inclusion in the Agreement

\footnotetext{
9 Judgment of the SOKiK of 14 February 2007, XVII Ama 98/06, unreported.
} 
of 'the option clause [had an] anti-competitive character and as such, it also affected public interest by restricting the possibilities of competitive growth on the related market of pay-TV. Consumers were therefore deprived of the possibility of benefiting from competition (establishing an optimum price to quality ratio). Canal+, for whom this entry barrier meant that it was not forced to engage in a competitive fight, was clearly $[\ldots]$ the beneficiary of such state of affairs'. SOKiK's opinion clearly contradicts the submission of Canal+ that saw itself as being better prepared, more experienced and possessing superior distribution channels than others, resulting in higher consumer benefits. The opinion that the pre-emption right put Canal+ in a privileged position cannot be refuted even though it never made use of this privilege. The issue of public interest violation as far as consumer benefits are concerned was not, however, proven convincingly.

\section{The fine}

Lowering the amount of the fine originally imposed on PZPN, SOKiK stated that 'It is not in the public interest for the claimant to suffer an excessive fine' because PZPN, under the Act of 29 July 2005 on qualified sports, performs tasks of a public service character. SOKiK created thus an interesting problem here concerning the existence (or lack thereof) of the necessity to take into consideration public interest issues when imposing antitrust fines.

The Court of Appeals did not share SOKiK's view stating that 'adopting such a position would create an unacceptable privilege for entities performing public tasks'. It is difficult to disagree with the opinion of the Court of Appeals as it reflects the constitutional principle of equal treatment of entrepreneurs. However, the Court went much further in its deliberations. 'Seeing a worse financial standing of a given enterprise as a mitigating condition [when imposing fines], would equal to assigning an unjustified competitive advantage to enterprises that are worse adjusted to market conditions'. Taking into consideration that the proceedings at hand concerned a vertical agreement, the Court of Appeals' conclusion seems to be too far-fetched. An agreement between two entrepreneurs of whom one operates on a highly competitive market, whereas the other enjoys a dominant position, most often means that the financial standing of the former is worse than the situation of the latter. Concluding that the latter is worse adjusted to the market is unjustified.

The character in which PZPN operates constitutes another issue to be considered. The Court of Appeals observed that 'within this scope, the claimant operates similarly to a royalty collection and distribution society rather than an entity realizing the tasks of a public character'. Unfortunately, the Court of Appeals did not draw any conclusions from its own observations leaving unanswered the question of what consequences does the fact have that PZPN operates similarly to a royalty collection and distribution society (so-called collecting societies).

Two questions arise here: (1) how to treat entities performing public tasks when imposing a fine and; (2) how (in the same case) to treat PZPN seeing as it was deemed to resemble a royalty collecting society? 
According to the Polish Competition Act, the fine imposed by the UOKiK President shall constitute a derivative of the revenue for the year preceding the infringement ${ }^{10}$. At the same time, the Act refers to income tax provisions a given entrepreneur is subject to as far as the definition of revenue is concerned ${ }^{11}$. The obvious issue to be decided when answering both the first and second question is the evaluation which events cause the revenue to arise as defined by the Act on Legal Persons' Income Tax of 15 February 1992 (hereafter, UPDOP) ${ }^{12}$.

The provisions of this Act do not include the definition of the term 'revenue' albeit Article 12 UPDOP provides a catalogue of gains to which the Act assigns such character as well as a list of those which are excluded from tax revenues. Jurisprudence explains that it is the 'definite' character of a property increment that determines whether it is included into the revenues of a given legal person in such sense that it shall ultimately increase that entity's assets: 'only such values which increase property assets of the taxpayer, i.e. the ones he or she may dispose of as his or her own, are obtained monetary or pecuniary values according to Article 12(1)(1) [UPDOP] ${ }^{13}$.

Another issue important for the interpretation of the notion of revenue is the fact that income tax of legal persons is a personal tax, that is, tax on calculable financial gains of a given person (taxpayer), and rests upon such person. The provisions of UPDOP decide in relation to whom do tax obligations arise in connection with obtaining a given gain. Without an explicit legislative provision, the same gain in the same amount may not constitute tax revenue for two taxpayers. When analyzing the case of a fiduciary to whose bank account the creditor paid interests on bonds on behalf of the entity in favor of whom the fiduciary acted, a regional Administrative Court stated that in the light of the provisions of the act on income tax of legal persons, there are no grounds to assume that the fiduciary obtaining funds on behalf of the entity in favor of whom it operates is the payer of the income tax on these amounts ${ }^{14}$. Quoting this judgment is recommended here as the operations of a collecting society, to which the Court of Appeal equaled PZPN, are based on that very same fiduciary construction. Hence, deemed as revenue under the provisions of UPDOP is only a final and specified as to the amount (or estimated beyond doubt) change of asset

10 Article 106 of the Act of 16/02/07 on Competition and Consumer Protection (Journal of Laws 2007 No. 50, item 331, as amended), hereafter, the Competition Act.

11 Article 4 of the Competition Act.

12 Act of 15 February 1992 on Legal Persons' Income Tax (consolidated text: Journal of Laws 2000 No. 54, item 654, as amended).

13 Judgment of the Supreme Administrative Court, branch in Szczecin of 14 May1998, SA/Sz 1305/97, judgment of the Supreme Administrative Court of 27 November 2003, II SA 3382/2002.

14 ' (...) from the point of view of settling who is the taxpayer of the income tax on the revenue resulting from the interest it does not matter to whose account the payment of such interest was executed. The fact that the payment was made as a result of the disposal of the owner of the bonds to the account of a different entity does not make the later one the taxpayer obliged to pay the tax' - judgment of the Voivodeship Administrative Court in Warsaw of 31/08/07, III SA/Wa 629/07. 
conditions whereby the taxpayer subject to the change is able to dispose of such increment as the owner.

Although the above should not raise any doubts, it is worth noting that International Accounting Standards (hereafter, IASs) are more precise in specifying the notion of revenue. IAS 18 Revenue states that 'in case of relations resulting from an agency agreement, gross income on commercial profit includes the amounts collected on behalf of the mandator and do not result in increasing the equity of a business entity. The amounts collected on behalf of the mandator therefore do not constitute the revenue. The amounts of commission however do constitute the revenue'.

There is no room to decide whether the accounts presented by PZPN saw as revenue only items which do, in fact, constitute revenue according to Polish tax law. It is certainly in the interest of an entrepreneur to present the UOKiK President with correct documentation. When comparing PZPN to a collecting society, the Court of Appeals should have, therefore, commented on the scope of verifying the correctness of specifying the basis of the penalty because this was a completely novel issue in the proceedings.

\section{Conclusions}

SOKiK started a discussion, which the Court of Appeals failed to continue, about the consideration of public interest when setting the amount of an antitrust fine. Regardless of the fact whether it could have reached a conclusion different to the one above, it is clear that the current fine system has many faults. Failure to comment on the issue of the correctness of ascertaining the basis for the fine must therefore be criticized.

On the one hand, the Competition Act states that it is applied in the public interest, which should mean that the authority takes this very interest into consideration also when imposing a fine. Series doubts arise, on the other hand, about connecting the amount of fines with revenue without establishing a simultaneous connection with the economic results of the infringement. This is confirmed by postulates de lege ferenda formulated by part of the Polish doctrine arguing in favor of creating a closer interconnection of the amount of the fine imposed and the actual effects of the violation. This standpoint is clearly reflected in the documentation prepared within the amendment procedure of the Competition Act which is currently underway ${ }^{15}$. It was observed therein that the present system of imposing fines on the basis of revenue only results in a lack of causality between the influence (actual or potential) of the prohibited practice and the imposed fine. Granting primacy to the abstract, and largely artificial, relation between fines and turnover infringes the constitutional principle of proportionality of penalties ${ }^{16}$. The impact of the effects of violations is emphasized in the European Commission Guidelines on Fines also. Accordingly: 'in order to set

\footnotetext{
15 www.uokik.gov.pl

16 Comments of the Competition Law Association work group to the assumptions for the bill of the Act on amending the Act on Competition and Consumer Protection, available at:
} 
the amount of the basic fine the Commission shall take into consideration the value of sale of goods or services realised by the enterprise having a direct or indirect link with the infringement, in a given geographical sector within EEA ${ }^{17}$.

The Court of Appeals stated that 'the provisions of the [Competition Act] do not provide the basis to deem that while settling the amount of the fine for an [antitrust infringement] one is to take into consideration, as an important factor, the fact that the entrepreneur is performing mandated tasks of a public character and therefore his financial situation caused by the necessity of paying the above-specified fine shall impact the realisation of those tasks'.

This opinion of the Court of Appeals is entirely correct - there are no reasons to differentiate between entrepreneurs on the basis of the public task criterion. However, the Court of Appeals failed to resolve some of the doubts expressed by SOKiK seeing as its judgment lacked a detailed analysis of the basis for the penalty (claimant's revenue). As it was deemed that within the scope covered by the proceedings PZPN operated as a royalty collecting society, failure to verify the correctness of defining its revenue must be criticized. While the claimant, quoting its 'specific' status of an entity performing public service tasks, had the chance to refer to the opinion of the UOKiK President, it did not have a chance to refer to the opinion that it operates pursuant to the principles applicable to collecting societies. Comparing PZPN to such entities means that the Association is deemed (within the scope the proceedings concerned) to be acting on the basis of the fiduciary model, which leads to a number of consequences within the scope of tax law, among others, within the scope of the amounts collected on behalf of 'members of the association' (in this case football clubs), which should not be taken into consideration as PZPN's revenue for the purpose of setting antitrust fines.

Tomasz Bagdziński, Ph.D.

Assistant professor at the European School of Law and Administration, practictioner, admitted to the bar.

Author would like to thank for help and assistance to Aldona Zaleska (tax advisor) and Dariusz Tarabasz (barrister trainee).

http://legislacja.rcl.gov.pl/docs//1/43452/43453/43456/dokument37461.PDF?lastUpdateDay=03. 08.12 \&lastUpdateHour $=4 \% 3 \mathrm{~A} 06 \&$ userLogged $=$ false $\&$ date $=$ Saturday $\% 2 \mathrm{C}+4+$ August +2012

17 Guidelines concerning the principle of setting the fines imposed under Art. 23(2)(a) of the Regulation 1/2003, OJ [2006] C 210/2. 